\title{
PUTTING PEOPLE LAST: LESSONS FROM THE REGULATION OF MIGRATION IN RUSSIA AND TAJIKISTAN
}

\author{
Olga R. Gulina ${ }^{1}$ \\ Doctor, Chief Executive Officer of the RUSMPI, \\ Institute on Migration Policy. \\ E-mail: contact@rusmpi.org
}

\section{Leah M. Utyasheva ${ }^{2}$}

Doctor, RUSMPI Researcher and a Consultant in International

Human Rights Law Based in Toronto, Canada.

E-mail: lutyasheva@gmail.com

\begin{abstract}
This paper analyses the recent developments and general direction of migration policy in two former Soviet Union countries - Russia and Tajikistan - from the lens of the current narrative in the field of migration research, paying attention to the economic and demographic reasons for migration, its legal and political framework, and the nascent integration and inclusion programs. While explaining the roots of the existing migration policy, and distinguishing between the migration policies of sending and receiving countries, the paper defines such terms as migration regime, migration mechanisms and migration regulations. The paper concludes that Russian migration policy reflects the inconsistency between the de jure liberal principles/ norms and their de facto restrictive application. The deeply embedded desire to limit an influx of the "Other" in Russia presents a serious threat to migration policy and the future economic development of the country. By contrast, while developing a comprehensive legislation, Tajikistan lacks the political will and resources to monitor its implementation and progressively demand the delivery of the results.
\end{abstract}

Keywords: Russia; Tajikistan; migration policy; migration regime; migration mechanism.

Citation: Gulina, O.R. \& Utyasheva, L.M. (2016). Putting People Last: Lessons from the Regulation of Migration in Russia and Tajikistan. Public Administration Issues, no 5 (Special Issue, electronic edition), pp. 92-118 (in English).

\footnotetext{
1 Gulina Olga R. holds a PhD in Migration Law (2010, University of Potsdam, Germany), a PhD in Constitutional Law (2002, Bashkir State University, Russia), Certificate of Advanced Studies in Human Rights Law (2005, Helsinki Human Rights Foundation, Poland), Diploma in Law (Law Institute of Bashkir State University, Russia).

2 Utyasheva Leah $M$. is a graduate of the Bashkir State University, Ufa, Russia. She holds an LL.M. in Comparative Constitutional Law from the Central European University, Budapest, and a PhD in Human Rights Law from the University of Newcastle, United Kingdom.
} 


\section{A little bit of theory}

There is a lack of common terminology for describing national migration policy, strategies, regimes, and mechanisms, and for distinguishing one from another, due, not least, to the broad range of notions included in these terms by academics, practitioners and national stakeholders. Nowadays various terms such as a "migration policy” (Geddes, 2002; Boswell, 2003; Chudinovskikh \& Denisenko, 2004; EU Commission, 2015a); "migration regime" (Kosnik, 2014); "migration management" (Thym, 2010, P. 50ff; Gulina, 2016 a, b), "migration control" (Light 2012; Buckley, 1995), and "state control over human mobility" (Torpey, 2000; Geddes, 2002; Eltis, 2002) have been used to describe and analyze state activities in regulating migration flows.

It is important to note that migration strategy, migration policy and migration mechanisms differ from each other, as well as the fact that the migration policy of sending countries vary from the migration policy of receiving countries. In this article, migration policy is understood as "rules (i.e., laws, regulations, and measures) that national states define and [enact] with the objective of affecting the volume, origin, direction, and internal composition of [...] migration flows" (Czaika and de Haas, 2013, p. 489). Migration policy as overarching government views, priorities and long term goals related to immigration and emigration should be distinguished from the migration regime, which is formulated to frame the policy, and depending on the country of migrant origin, migrant educational background, and other circumstances, could for example be liberal, restrictive, or neutral. Migration regime, as Kosnik suggests, is "the outcome of a field of forces where different kinds of agencies and institutions intervene, including migrants themselves" (Kosnik, 2014). The migration regime determines the practical implications of the migration policy in the short- to medium terms. Migration mechanisms such as visas, quotas, residence and work permits, etc, comprise the components of the migration regime. Migration mechanisms together with the migration regime and migration regulations (laws, decrees, strategies) comprise migration policy.

There is a plethora of scholars whose work is based on analysis of migration policy and their key-mechanisms in different countries. Mayda and Patel (Mayda \& Patel, 2004) review the migration policies in 14 OECD countries over the period 1980-2010; Bjerre et all (Bjerre et all, 2014) analyse the immigration policies in 33 OECD countries over the same period; Ruhs (2011) compares 46 countries and their migration policies for regulating labor migration in 2009; de Haas et all (de Haas, 2015) tracks migration policy changes in 45 countries between 1945 and 2014. Given previous scholars' work, the current paper outlines the migration policy specifics of the migrants' receiving country (Russia) and the migrants' sending country (Tajikistan).

The German scholar Ulf Rinne views migration policy through two mutually linked components: a) the selection and settlement ("mobilization") component, which sets the rules for individuals' entry, exit and stay in the country; and b) integration policies and programs that aim to improve the economic and social outcomes of newcomers (Rinne, 2012). The first type of immigra- 
tion policy aims at managing quantity, professional quality, and the educational, gender and social background of immigrants in the host country. Immigration countries use various mechanisms, such as a points-based system (Canada, New Zealand), labor quota (Russia, the USA) and other legal restrictions and/or preferences (EU, EUEA) ${ }^{3}$.

The second type of immigration policy - or integration policies - include measures such as: a) welcome programs, b) language training, c) labor market programs, and d) anti-discrimination policies (Eurostat, 2011). Without a doubt, programs, initiatives and measures aimed at immigrants' integration are considered to be the most important component for a successful immigration policy of migrants' receiving countries (Schulte \& Bayat, 2007, p. 22; Craig 2015; Malakhov, 2015; Varshaver \& Rocheva, 2016). Both components depend on the state's and society's interest in (re)integrating or disconnecting with newcomers.

While Rinne's scheme accurately reflects migration policy in receiving countries, applying this scheme to sending countries will produce different results. To adequately analyze migration policy in sending countries, the above two components transform into the following:

The selection and settlement component will include measures aimed at: a) the creation of domestic jobs and limiting migration flow abroad; b) assistance in migrant selection and settlement in receiving countries, and c) measures at increasing the employability of migrants;

The integration and reintegration measures include: a) activities aimed at developing repatriation programs and supporting returnees after they come back home; b) protection of its nationals abroad, including social and human rights aspects; and c) agreements aimed at harmonizing social support, pensions, and tax issues between the countries. Migration and (re)integration as facets of public life adopt a specific legal framework depending on subjective and objective factors shaping and influencing it.

Rinus Penninx et al (Penninx, 2008) note that before the 1990s, migration and integration had established themselves as "more or less independent fields of research and theory". This has led to the striking difference between migration policies' promises and their application in the real life (Penninx, 2003; Joppke $\&$ Moravska, 2003). Nowadays integration policies are used to improve the economic and social outcomes of newcomers, to support those settlers who are willing to become a part of the host society and to detect those who are not. In the 1990s, American sociologist John W. Berry put forward four concepts of immigrants' interaction with their host countries: marginalization, segregation, assimilation and integration (Berry, 1997). Unsurprisingly, countries try to avoid marginalization and segregation, and even assimilation strategies are considered perilous (Spencer, 1997; Hansen, 2000). Integration and re(integration) has become a key element of modern migration policy. However, integration or inclu-

\footnotetext{
The EAEU member states, i.e. Russia, Belarus, Kazakhstan, Kyrgyzstan and Armenia, promote the free flow of goods, services, labor and capital among its members. According to the EAEU treaty, member states are not allowed to implement any restrictions on the labor force from other member states. The employers are allowed to hire workers without special permission. Workers can stay in the host country as long as they have a valid employment contract. Without a contract, they are limited to stays of 90 days (like all other CIS citizens).
} 
sion (Duszczyk \& Góra, 2012; Houtkamp, 2015) - as the next step of integration - need to take into account those factors which often influence the outcome of migration - country of migrant's origin, length of their residency, and personal background. Successes of inclusion need to be measured by the wellbeing of migrants and their offspring, elements which are able to show the outcomes and successes of inclusion policy in the best fashion (Saggar et al. 2012, p. 19).

\section{Geographic and Economic Scope and Background}

The geographical scope of the current paper is determined by the common historical background, social-linguistic ties between inhabitants, and the high numbers of labor migrants coming from Tajikistan to Russia. Sharing a common "Soviet" past, Russia and Tajikistan have opposite migration flows (with Russia being the receiving country, and Tajikistan being the sending country) and subsequently different political-legal components in their migration policies.

In 2015, the GDP of Tajikistan was 48.40 billion TJS, or about 7.87 billion USD - making it one of the poorest countries in the region- and 1.9 billion USD, or above $24 \%$ of the GDP, were the recorded remittances of Tajik migrants working in Russia (Agency on Statistics 2016 \& Central Bank, 2015). The World Bank provides an even higher number - according to its estimates for 2014, Tajikistan remittances contributed to up to $42 \%$ of the GDP, equaling 3.1 billion USD. In 2015, when the number of Tajik migrants in Russia decreased by 3.8 percent due to the economic crisis and the fall of the ruble, the estimated decline in remittance receipts in Tajikistan was as high as $24 \%$ (World Bank, 2016).

More than 1.5 million foreign workers are employed in Russia annually on the basis of labour patents (RIA Novosti 2015). Tajikistan provides the second-largest number of labour migrants to Russia after Uzbekistan. The leading Russian demographic expert Zhanna Zayonchkovskaya expects that by 2030, labour migrants from Tajikistan will replace labour migrants from Uzbekistan as the largest ethnic migrant group on the territory of the Russian Federation. (Zayonchkovskaya, 2016).

Before the devaluation of the Russian rouble, more than $84 \%$ of all labour migrants from Tajikistan chose Russia as their destination country, with the rest going to Ukraine, Kazakhstan and other countries (Ryazantsev, 2016). With high numbers of people of employment age and the low level of infrastructure development and a limited domestic labour market, $9 \%$ to $25 \%$ of the Tajik population of employment age goes abroad for work. According to official data from the Migration Department of the Republic of Tajikistan, 744000 labour migrants were registered in 2013 (about $9 \%$ of the total Tajik population of 8 million). Local experts estimate that up to 2 million Tajik citizens are migrants who travel abroad for varying periods of time, usually for labour (WHO Europe, 2014). The majority of them choose Russia as their final destination. If in today's Russia one worker leaving the country is replaced with 12 who arrive, in Tajikistan, one newcomer entering the country is replaced with 600 who leave (Rayazantzev \& Horie, 2011, p. 44).

And this is not surprising - in 2009, the average monthly salary in Tajikistan was equivalent to 68.6 USD, which is the lowest wage in the Commonwealth of In- 
dependent States. In contrast, average salaries in Russia in 2009 were 689 USD. Unemployment rates were 5.5\% in 2013 in Russia, and $11.6 \%$ in Tajikistan, which is the highest in the region (Ryazantsev, 2016). Work abroad remains the most important factor in the economic development of the country where unemployment is the highest among young people and women.

Russia needs the labor force and demographic potential that immigrants bring, as it belongs to the category of countries with a shrinking population, birth rates below substitution and rapidly increasing numbers of people of old age. According to the Russian statistics office, the numbers of people of employment age has been decreasing since 2011 and will continue its sharp decrease during the 21st century. In 2011-2020 the number of people of employment age will decrease by 9 million or a staggering $8-10 \%$ of the total (Klepach, 2013). In 2014, the Federal State Statistics Service of the Russian Federation presented three possible demographic estimates for Russia, with low, medium, and high demographic scenarios which differ significantly from one another in terms of migration gain (the breakdown of migration inflow and outflow). According to the low scenario, the Russian population will be $145,404,600$ by 2025 , and will experience a migration gain of only 211,800 people. The medium forecast indicates a population of $148,341,600$, with a migration gain of 338,900 . The high scenario predicts $150,704,000$ people and up to 466,100 in migration gain. In all three scenarios net migration is a significant variable. However, the low and medium scenarios imply a general depopulation (a decline of 490,000 people in the low scenario and 36,900 people in the medium scenario) and indicate migration inflow as a way to maintain the current population size (Gulina, 2016; Federal State Statistics, 2015).

In contrast, in Tajikistan, in 2000-2012, the population increased by $29.4 \%$, and is currently 8.2 million, which is $42 \%$ more than in 1991, when Tajikistan became independent. The majority of these people are of employment age (15-64), and the proportion of the population in this category is rapidly increasing - in 2011 it comprised $61 \%$ of the total population. This creates stress for the economy and problems in providing employment for these people (Cooperation Program of the ILO and Tajikistan 2013).

Cumulatively, these factors raise a number of unique demographic, economic and development issues both for Russia and Tajikistan, underlining these countries interdependence on each other for economic growth and development, and stimulating the need for active collaboration in the migration sphere.

\section{Development of migration policy and institutions}

\section{Russia}

One can identify five stages in the development of the immigration legislation in the Russian Federation. The first (preparatory) stage, in 1997-2002, included the creation of a legal framework - the adoption of the Citizenship Law of 2002 (Law on Citizenship, 2002) and Law 115-FZ On the Legal Status of Foreign Nationals in Russian Federation of 2002 (Law on Legal Status, 2002), as well as the concept of Russia's demographic development until 2015 (Demographic Concept, 2015) - the instruments which set out the main principles for 
regulating migration. These laws specified the types of documents mandatory for foreign citizens and stateless persons residing in the RF: "vid na vremennoye prozhivaniye" - temporary residence permit, and "vid na zhitel'stvo" - permanent residence permit, and established requirements for the acquisition and loss of citizenship.

The second stage, in 2002-2006, signified the further development of migration mechanisms with the introduction of employment quotas for labor migrants arriving in Russia on the visa-regime, expanded and clearly specified the powers given to the Federal Migration Service (FMS), and signed agreements on labor migration within the CIS countries. Migrants from the CIS were generally exempted from the visa-regime. The institute of citizenship took form, with a somewhat simplified process for granting citizenship to citizens of the CIS. The definition of state interests within migration policy has taken place, as the country has started developing legislation and policy to further its strategic goals and national interests, with more detailed migration policies and strategies.

The third stage, in 2007-2009, called by national experts "a liberal revolution", included a) the simplification of the rules for hiring and registering labor migrants arriving in Russia on the visa-free regime, b) the introduction of employment quotas for migrants arriving in Russia on the visa-free regime, and c) reallocation of a portion of the migrant workforce from central Russia to the other regions such as the Urals, Siberia and the Far East.

The fourth stage began in 2010 and continued until 2015, with further detalization of migration mechanisms. Work patents for individuals arriving on the visa-free regime which allowed them to lawfully reside and work in the RF were introduced; companies received the chance to hire highly qualified professionals beyond the quotas set by the government; fingerprinting labor migrants arriving in Russia on the visa-free regime, when they are issued work permits, was introduced (Gradirovsky, 2010). Russia has started negotiations and entered into agreements with key labour migrant sending countries, in order to ensure a regulated migrant flow and implementation of the rules.

Presently Russia is going through the fifth stage, characterized by a striking lack of consistency. On one hand, the new Concept of Migrations strategy until 2025 (Migration Concept, 2012) for the first time recognized that migration is necessary to address the changes in the demographics of the country and counterbalance the decrease in the population. The Strategy has shifted from being concentrated on "limiting" migration flows, overcoming "migration crisis" and seeing migration as a threat to the security and wellbeing of the country, to paying more attention to attracting highly educated migrant pools and increasing the migration profile of the country abroad. The realization that Russia needs a migration influx for maintaining its labour market in order to compensate for the demographic decrease of the population was long overdue.

Another positive development happened after the involvement of the Russian Constitutional Court in 2015, bringing the policy in line with international standards. In 2015, the Constitutional Court found a restrictive rule outlined in the law "On the rules for exit from and entry to the Russian Federation", 
the law "On the legal status of foreign nationals", and law "On prevention of the spread of disease caused by HIV in the Russian Federation" requiring that migrants need to present an HIV-free certificate in order to enter Russia, to be unconstitutional (Constitutional Court, 2015).

At the same time, there are other legislative initiatives that could be seen as being anti-immigrant and strictly region-oriented. Federal law N 207 of July 27, 2013 introduced regionally differentiated liabilities for violating immigration rules 4 The Law 376-FZ, adopted at the end of 2013, introduced certain restrictions on the entry of migrants from the CIS countries, the so called 90 out of 180 days' regulation (Federal Law N 36 FZ), as well as sanctions, both for foreign and Russian nationals, for violating the registration requirements ("Rubber Apartments" Law). In January, 2015 a new system of obtaining patents was introduced, with stricter liability for violating patent terms. The new rules include requirements to pass a Russian language test, proof of knowledge of Russian history and the basics of the legislation, and proof of medical insurance. These examples of anti-immigration policy may be the tip of the iceberg, and some certainly seem geared toward constructing a restrictive migration regime for the citizens of the CIS.

New evidence of restrictive migration policy trends took place at the beginning of 2016, when power and duties of the Federal Migration Service were transferring from under the auspices of the Government of the Russian Federation to the Ministry of the Interior, thus underlining the law-enforcement incline in the policy as such, and emphasizing the view of migration as something that needs to be restricted and contained (Gulina \& Utyasheva, 2016; Decree, 2016).

\section{Tajikistan}

After the dissolution of the Soviet Union, Tajikistan, as with other countries of the former Soviet Union, had no experience in how to regulate migration and had no expertise related to policy development in this area. A national migration agency did not exist, and the necessity of its creation was not immediately apparent to decision-makers. Military conflicts created refugees and internally displaced persons requiring support and social protection. Transparent borders made easy transnational travel at a time when citizenship status was not defined and many people remained in neighboring countries without proper identification for years and even decades. Statistical data collection on migration did not exist.

\footnotetext{
4 For example, the failure of a foreign national or a person without citizenship to properly register in Moscow, the Moscow oblast, St. Petersburg, or the Leningrad oblast is punishable by an administrative fine of between 5,000 to 7,000 rubles (about \$200) and deportation from the Russian Federation (see Article 18.8 on the Code of Administrative Offences). Yet the same violation committed in other parts of the Russian Federation entails administrative fines of between 2,000 to 5,000 rubles with or without deportation. In fact, the law says that foreigners who breach immigration rules in Moscow ought to be deported, while in other Russian regions they might be allowed to stay. A similar territorial-specific approach to employers' responsibilities is manifest in new versions of Article 18.15 (on the "Unlawful engagement of a foreign citizen or person without citizenship in labor activities in the Russian Federation") and Article 18.16 ("Violation of the rules of engagement of foreign citizens and persons without citizenship in labor activities at trade outlets, including shopping complexes"). A violation of these rules leads to fines ranging from 400,000 to $1,000,000$ rubles (up to $\$ 30,000$ ) for employers in Moscow, and only 250,000 to 800,000 rubles in the regions.
} 
Over the next few decades however, after realizing the necessity and importance of migration policy, Tajikistan produced a relatively high number of migration concepts and strategies, and currently possesses a developed and constantly updated legislative and normative framework on migration and employment. The development of the legislation and policy framework in Tajikistan could be divided into three main stages. The first stage (1998-2008) concentrated on the establishment of institutions and regulations, trying at the same time to determine its direction and priorities for the future. Thus, in 1998, Tajikistan became one of the first Central Asian states to adopt a Concept of State Migration Policy (Tajikistan's Migration Concept, 1998). In June 2001, Tajikistan adopted the Concept for Labour Migration by Tajik Citizens Abroad (Tajikistan's Government Regulation, 2001), that encouraged unemployed citizens to become migrant workers in other countries. The second stage (transition stage) - 2008-2010 - while continuing to build institutional capacity, saw a temporary setback when many migrants were forced to return home because of the economic crisis of 2008 in Russia, and Tajikistan came to realize the necessity of negotiating its interests on a political level in order to facilitate the employment and status of its citizens abroad. This stage sparked conversation about the protection of Tajik labour migrants abroad.

The current third stage - 2010-2016 - includes further realization of national priorities, including attempts at redirecting and expanding migration flows from Tajikistan, protection of the rights and interests of migrant workers, raising their social guarantees, skills and potential of the labour force. This stage's political rhetoric underlines that the current high number of migrants is a temporary phase in the country's development. Observers note that all the migration documents of Tajikistan had one principal flaw - the envisaged activities were neither financially supported not connected to specific implementation plans and plans of action. The lack of implementation, including a lack of finances for putting strategies into effect, lack of political will to insist on it, and lack of developed action plans and ministerial responsibility for accountability hindered effective implementation of the migration policy in the country. It remains to be seen, if this stage in Tajikistan will be accompanied by a more comprehensive implementation of migration priorities.

The legislative documents of the current third stage include the National Strategy of Labour Migration of Citizens of the Republic of Tajikistan Abroad for 2011-2015 (Tajikistan's Government Regulation, 2011); Law On Combating Human Trafficking (2014), Law on Migration of 2013 (Tajikistan's Government Regulation, 2013), Law On Private Employment Agencies, Law on Improvement of Employment (2003), Strategy of National Development until 2015, State Strategy of the Development of the Labour Market until 2020 (Tajikistan's State Strategy, 2011), Strategy on Improving the Wellbeing of the Citizens of Tajikistan for 2013-2015 (2012), and the State Program on the Realization of the Concept on the Development of Legislation in Spheres of Labour, Social Protection and Education for 2012-2015 (Tajikistan's Government Decree, 2012).

The legislative framework of the current stage could be seen as part of a complex, as one body of legislation with defined objectives and priorities, with migration issues streamlined into other normative document. Migration issues as a de- 
velopment factor is taken into consideration in the Migration strategy. Labour migration issues play a significant role in the National Development Strategy (2015), and the Poverty Reduction Strategy for 2011-2012 of Tajikistan (GIZ, 2012). The National Program on the Enhancement of Employment (2004), also prioritizes the creation of new jobs, new mechanisms for partnerships between employers and employment agencies aimed at creating new jobs, the creation of a database of available vacancies, and measures aimed at determining demand and supply in the area of employment (no 19, para. 41).

The migration strategy is meant to regulate and manage labour migration, in order to incorporate migration policy in a broad developmental model and to elaborate sensible and thought-through policies with a specific road map for implementation and financing. It serves as the main guiding document for the implementation of the objectives of the National Development Strategy in the area of labour migration management, giving priority to the creation of new employment and the upgrading of existing jobs, the preparation of migrants for work abroad, and the protection of labour migrants' rights and interests in other countries.

The stated priority of migration policy in Tajikistan is the creation of employment in Tajikistan itself, with labour migration seen as a temporary measure aimed at reducing pressure within the country. Curbing illegal migration, and the creation of bilateral and multilateral agreements directed at migrant protection, as well as the establishment of new markets through the development of international cooperation, are among the stated priorities of the government. The National Strategy of Labour migration of citizens of the Republic of Tajikistan abroad for 2011-2015 (hereafter Strategy) proposes activities for the reform of the outdated existing system. The main directions of the Strategy are more people-focused that in previous documents, including social-economic and legal protection for migrant workers, and the high quality professional education of migrants. The overarching message of the Strategy is that migrant labour is not a commodity, but rather an asset of the country, to be cherished, preserved and developed. The Strategy also mentions the necessity of measures aimed at forming a positive image of Tajik migrants abroad.

\section{Migration mechanisms}

Migration mechanisms form part of the migration policies, and consist of rules for entry, stay and exit. They are designed to manage the flow of migrants and exist to ensure residence permits, labour certificates and visa grants are in line with the government's annual planning level. States possess the broad authority to regulate the movement of foreign nationals across their borders and on their territory through passports, visa-admissions, a points based system, quotas, residence provisions, exclusion and expulsion of aliens, and frontier controls (Martin, 2003, pp. 31-3). Due to space limitations, in-depth discussion of the visa regime is beyond the scope of this paper and we therefore concentrate on migration mechanisms more closely related to the discussed topic instead (i.e. the right work). 


\section{Russia}

The rules of entry to and exit from the Russian Federation, visa arrangements and the legal status of foreigners and stateless persons on the territory of Russian Federation are ruled by laws on the Legal Status of Foreigners of 2002, Legal Entry To and Exit From the Territory of RF of 1996, and the Migration Registration of Foreigners and Stateless Persons of 2006. Russian migration policy uses diverse migration mechanisms, i.e. quotas, temporary work permits, patents (and various requirements to get them, such as culture and language exams) both for labour migration and resettlement on the territory of Russia.

As part of its migration mechanisms, the Russian government sets up temporary residency permit quotas for foreigners according to Article 6 of the Law on Legal Status of Foreigners. According to Government Regulation N 2197-P of October 29,2015, the annual quota for temporary residency permits was set at 125,900 in $2016 ; 151,175$ in 2015; and 146,627 in 2014. A temporary residency permit might be granted to a foreign national on the territory of the Russian Federation outside the quota (Art. 6-3, Law on Legal Status of Foreigners) in cases whereby he/ she:

- Was born on the territory of the RSFSR and was a citizen of USSR;

- Is married to a citizen of the Russian Federation residing on the territory of Russia;

- Has at least one disabled parent who is a citizen of the Russian Federation;

- Has a child who is a citizen of the RF;

- Has invested the amount set by the Government of the RF, etc.

Additionally, the Russian government annually introduces educational quotas for foreign nationals interested in obtaining secondary education, advanced education, or doctoral and post-doctoral education programs on the territory of Russia (Government Regulation 2013). In 2014, the educational quota for foreign nationals was 15,000, including participants in the Compatriot Return Program (Ministry of Education Decree, 2014).

Some important migration mechanisms that set Russia apart from many other countries, and deserve to be discussed in this article, are those in the State Program of Support to Voluntary Return to the RF of Compatriots Residing Abroad (hereafter: Compatriots Return Program).

The Compatriots Return Program serves as an instrument to help solve the country's demographic and economic problems. Russian regions are divided into territories with priority resettlement and other territories (President Decree, 2012). Before 2013, regions of Russia participating in Russia's State Program of Support to Voluntary Return to the Russian Federation of Compatriots Residing Abroad had been divided into three categories: border territories strategically important for Russia and characterized by shrinkage of the population" were registered as the category of priority settlement (category A); territories where large investment projects are carried out requiring mass participation of resettlers due to the labor force shortage on the local market (category B); territories with stable economic development where over the past three or more years the overall population size has been falling or population drain had been recorded (category C) (Law 99-FZ). 
Nowadays, the regions of Russia participating in Russia's State Program of Support to Voluntary Return to the Russian Federation of Compatriots Residing Abroad are divided into two categories: territories with priority resettlement and other territories (President Decree, 2012).

The Compatriot Return Program's participants enjoy the highest level of state support in the Far Eastern and Siberian Federal Districts, particularly in the Republic of Buryatia, Khabarovsk Region, Magadan Region, Sakhalin Regions, the Jewish Autonomous Area, etc. It could be argued that the heavy emphasis on the relocation of compatriots was dictated by the country's desire to limit its migration flows to culturally homogeneous and ethnically Russian citizens of the former USSR, and had its roots in the historic unease with different cultures and lack of interest in integrating migrants, and adapting society to a more tolerant and diverse environment.

\section{Tajikistan}

The rules of entry to and exit from Tajikistan are ruled by the law of the Republic of Tajikistan on the legal status of foreign citizens, and the Rules on Stay in Tajikistan for foreign nationals (Tajikistan's Law on Legal Status, 1996; Tajikistan's Government Decree, 1999). Foreign citizens need entry and exit visas, and if foreign citizens stay in Tajikistan for longer than 6 months they need a residence permit (Art 5).

As outlined above, the selection and settlement component in a sending country includes measures aimed at: a) the creation of domestic jobs and limiting migration flow abroad; b) assistance in migrant selection and settlement in receiving countries, and c) measures at increasing the employability of migrants in general.

As mentioned above, one of the stated national priorities of Tajikistan is to increase economic development in the country by creating domestic jobs. The State Program on the Employment of Citizens of the Republic of Tajikistan (20142015) emphasizes domestic job creation, improving the economic outlook of the country and encouraging entrepreneurship and small business creation, as well as government support for unemployed and vulnerable groups. It also includes assisting people in finding employment domestically, cooperation between employment agencies and employers in order to ensure synergy in the direction and mechanisms of creating new jobs, and helping people improve their employability. In order to increase employability of certain vulnerable groups, there are a number of activities, such as quotas, promotion of education and vocational training and re-training, self-employment and small business, and professional counseling. Measures aimed at an increased employability of youth are given priority (Tajikistan's State Program on Employment, 2014).

Tajikistan's extensive network of State Migration Services cover every region of the country and several offices in Russia work primarily to provide assistance with migrant selection and settlement in receiving countries. The Migration service operates a network of pre-departure centres for counseling and training migrant workers. However, according to observers, the State Migration Service is a weak institution which, despite its wide institutional mandate, struggles to fully achieve its mandate. It only registered $10 \%$ of the entire number 
of labour migrants, and struggles to operate the system of professional education and training. A network of private employment /recruiting agencies was created to help prospective migrants find employment in the receiving country. In addition, the government developed a labour market information system, designed to help connect employers and job seekers. However, due to the lack of regulation capacities and low demand by potential migrants, the impact of these initiatives is low (GIZ, 2012, p. 5).

Tajikistan operates on bilateral agreements with destination countries aimed at protecting the rights and interests of migrants, and educational and professional development. For example, it directs increasingly more energy to the adaptation of its workers in Russia, helping them find employment in the host country, adapting their skills to the host country's job market, and even providing vocational training for professions in demand in Russia, and assisting migrants in getting necessary papers and obtaining employment abroad. It also signs bilateral agreements between host and source countries related to labour migration, promoting cooperation between host and source countries' employment agencies (Tajikistan-Kuwait Agreement of August 16, 2011; Russia-Tajikistan Agreements of 1992 and of 2013).

Currently, the Russian-Tajik intergovernmental commission has prepared a series of additional accords complimenting the framework migration agreement, aimed at providing the organized and orderly recruitment of migrants to Russia by official Russian agencies; strengthening the information flow about persons violating visa and migration regimes, and signing agreements about re-admission (which presupposes Tajikistan's consent to take back irregular migrants deported from Russia). One notable gap in the discussed normative framework is the absence of performance evaluation indicators, responsible agencies, action plans and a clearly defined time frame for the implementation and monitoring of the above documents.

It is important to mention that both countries are currently engaged in intergovernmental discussions about the introduction of a visa regime for the nationals of Central Asian countries in order to enter Russia. In early 2013, members of the Communist Party and the Liberal Democratic Party of Russia proposed amendments to the migration legislation in order to introduce visas for Central Asian nationals entering the territory of Russia. The idea has been discussed broadly for a number of years but so far it has not come to fruition due to the demographic, economic and geopolitical interests of Russia in those regions (Gulina, 2013). The discussion is however continuing.

Nowadays, an apt management of migration flows, which includes decisions on visa arrangements, is part of the political process which defines and is being defined by economic, political and socio-cultural relations between countries (Berg et al, 2006; Sedelmeyer, 2002). Both current cases - Russian and Tajikistan - have shown this in a clear way. A visa regime restricts a person's freedom while enabling nation states to make individual decisions about the need for or desirability of any single person's sojourn in the country (Salter, 2004). A visa-free regime means a high level of trust and confidence between the states that have mutually agreed to it and enhances the degree of citizens' freedom. 


\section{Migration mechanisms as a part of integration policy}

\section{Russia}

Russia presently does not have an integration strategy. Discourse on immigrant integration is limited to strategies such as an obligation to pay for a Russian language course and an obligation to get a Russian language proficiency certificate. In 2010, the former Federal Migration Service, established a Board for Promoting Integration (FMS Order, 2012). The Board's departments were authorized to develop a strategy for integration and interaction with NGOs and ethnic organizations, and to liaise with the public and the media at a federal level. The creation of the Board had not been followed by the creation of similar agencies under the patronages of regional migration services nor did it have an impact on the law-enforcement practice. As a result of misleading policies toward newcomers, the general population still sees migrants in Russia as a threat that needs to be subject to tough controls, and not as people in need of integration support:

- $\quad 71 \%$ of Russians are convinced that immigrants are mostly criminals and support their deportation.

- $\quad 73 \%$ support tough measures by the authorities against immigrants.

- $\quad 53.3 \%$ view them as ignoring Russian language and culture, and having difficulties in communication.

- $\quad 42.3 \%$ characterize them as low skilled and poorly educated persons.

- $\quad 35 \%$ are irritated by the "untidy and repulsive appearances" of newcomers.

- $\quad 18.7 \%$ disapprove of their bad manners and indelicacy (Levada, 2013).

However, there are a number of initiatives towards immigrants, at least in theory, designed to facilitate their adaptation to modern Russia.

The urgency of language unity was stated by President V. Putin, when in 2002 he mentioned that "it is important that newcomers have a chance for adaptation in the country. Reaching this goal is our elementary requirement to the newcomers wishing to live and work in Russia, their readiness to learn Russian culture and language" (Putin, 2012). Since then, the reasons for which Russian language proficiency needs to be proven, has expanded.

First, a Russian language test, as a precondition for obtaining citizenship of the Russian Federation, was introduced by the Decree of the Russian President on November 14, 2002 (President Decree, 2002a). Ten years later, language requirements had significantly broadened and included migrants working in social spheres. In November, 2012 the new law came in force, obliging migrants employed in the field of housing and communal services, trade and consumer services, to pass an examination comprising the Russian Language, Russian History and Basics of the Russian Legislation (Federal Law N 185 FZ). A foreign citizen submitting an application for a work permit or extension of a work permit in the fields of housing and communal services, trade and consumer services is required to provide a document proving their knowledge of the Russian language.

This rule is being developed further: the introduction of compulsory examinations in the Russian Language, Russian History and Basics of the Rus- 
sian Legislation must be introduced to all foreigners regardless to their status and legal document. The draft mentions that such provision will ensure a more effective social adaptation and integration of migrants into Russian society and at the same time will contribute to easing tensions and preventing threats to interracial harmony.

A number of regional and local programs exist in Russia aimed at immigrants' deeper knowledge of Russian language and culture. For example, since 2012, St. Petersburg has run the Program for Harmonization of Intercultural, Interethnic and Interfaith Relations, Promoting a Culture of Tolerance for Newcomers in St. Petersburg (St. Petersburg's Program, 2010). Within the framework of the program various courses and educational activities for immigrants have been organized. The special language and adaptation courses for women and youths designed by the NGO "International Information Centre" and the Regional Office of the Commissioner for Human Rights in the Sverdlovsk Region has been popular among migrants in this region.

- Adaptation of migrants through community initiatives

There are few initiatives towards immigrants' adaptation supported and structured by the civil society sector in Russia. Targeting the change in the situation at the end of 2013, the Ministry of Regional Development developed a document that established financial and institutional assistance and support from the state to the NGOs dealing with the social and cultural adaptation and integration of immigrants. The idea of adaptation and integration appeared in Russian immigration discourse as part of the FMS' initiative in March, 2014. The government planned to require the new immigrants coming into Russia to sign an "adaptation contract" upon arrival if they wished to obtain a residence card and/or working permit (Law Draft, 2014). This idea is still under consideration.

\section{(RE)Integration policy of Tajikistan}

Integration and reintegration measures in the sending countries include: a) activities aimed at developing repatriation programs and using skills of returnees in the domestic labour market after they are back home; b) protection of its citizens abroad, including social and human rights aspects; and c) agreements aimed at harmonizing social support, pensions, and tax issues between sending and receiving countries.

Tajikistan has achieved some headway in developing its job-market and its national economy. National analysis shows that the jobless rate in the country have been slowly falling, with new jobs created in agriculture, food and sales. However, the number of people working in the manufacturing sector has fallen, resulting in the de-industrialization of the economy (Ryazantsev, 2016).

Tajik migrant workers could be divided into two groups, the first being seasonal workers who come to work in agriculture and construction, and who typically return home for the colder months. This group of Tajik citizens comprises $75-80 \%$ of all seasonal migrant workers in Russia (Ibid). The second group remains in Russia for extended periods, but frequently lacks legal status. Therefore, any questions on the social protection of migrants after and during their employ- 
ment in Russia, as well as human rights protection, are problematic subjects for Tajik national reintegration policy. Measures to protect migrants in the host country include Tajikistan, through multilateral agreements and negotiations, trying to increase the possibility of its citizens obtaining right of residence, employment protection and social security, as well as the transferability of social benefits acquired abroad.

Another point of discussion is the impact of Tajik migrant remittances on country development. Paradoxically, the remittances that migrants send back to Tajikistan do not lead to significant investment in the local production. There is evidence that migrants and their families invest only small sums in developing businesses and enterprises. Money transfers from migrants in Russia stimulated growth only in one particular sector of the economy - construction - with many Tajik workers using the money to remodel and build new homes. No doubt, remittances stimulate consumption and the economy in general in Tajikistan, however, unfortunately red tape and a lack of government incentives preclude people from starting their own businesses and investing in production and services in Tajikistan. Due to the lack of any coherent policy, the impact of many labour migrants living and spending money in their host country is also limited. Thus, the (re) integration mechanisms are still less designed to meet Tajikistan's economic and social needs and migration demand.

\section{Challenges and negative consequences posed}

by the violation of migrants' rights

The challenges posed by migration with the gaps in regulation and policy are largely predicated on the lack of cooperation and coordination between the interests and migration policies of the receiving country and the sending country. The negative consequences of the current mismatch between the migration policies of Tajikistan and Russia has resulted in migrants' human rights violations, a lack of social protection and guarantees, and a growing level of xenophobia and anti-migrant movements among the general public in Russia. Migrants' rights are part of modern migration policies and abuses of migrants' rights are one of the most hotly debated issues today (Abashin, Pashkova, Varschauer).

\section{Right to Education}

Numerous facts on immigrant workers' children being denied admission into public schools are reflected in the "Memorial" report on "The situation of children from vulnerable groups in the Russian Federation" (Memorial Alternative Report, 2014 , pp. 31-34). The report rates amongst the discrimination practices, the requirement of migrant parents to provide additional documents to enroll their children into a public school, made by authorized educational bodies, based on the Order of the Education Committee of St. Petersburg N 1674 from 07.07.2012. It is estimated that there are 138.000 children from Tajikistan in Russia, which is almost $12 \%$ of all foreign minors in the country. Although, theoretically, there should be no barriers for children of migrants to enroll in day-care or school in Russia, in reality, it is often unaffordable. 


\section{Right to health care}

The right to quality and professional medical care is dependent on the immigrant's legal status, residence permit, the existence of an employment contract, and the certificate of compulsory health insurance (CHI).

Among all of the above mentioned documents, the certificate of compulsory health insurance is the most significant for getting health care services in Russia. Its existence means that the foreign national is employed on the territory of Russian Federation through an employment contract, and that his/her employer contributes, as required by law, compulsory health insurance fees to the Federal Compulsory Medical Insurance Fund and their territorial health insurance offices (Federal Law N 212-FZ). According to Regulation N 186 of Rendering Medical Assistance to Foreign Citizens, approved by the Government of the Russian Federation in March, 2013, only those immigrants can get free (unpaid) access to professional health care services in Russia

However, there are difficulties in realization of the right to health care for immigrants due to the "wasteful costs of medical insurance policy, lack of motivation for employers to protect the immigrant workers' health and the lack of free choice among medical facilities in case of compulsory medical examination" (Kuznetsova \& Mukharyamova, 2014). To solve these problems, the Russian Ministry of Labor and Social Protection introduced, in June 2013, draft legislation obligating employers and their employees to buy private, voluntary medical insurance. According to the authorities' information, the initial cost of the voluntary medical insurance could be from 500 Rub up to 12000Rub (Yevplanov, 2013) and could resolve the difficulties in realization of the right to professional medical care for immigrants.

Before 2011, according to reports, there had been no problems with migrant children obtaining health care, even when they did not have the necessary documents. More than $70 \%$ of migrant children received the necessary health care, more than half of them free of charge. Since 2011, the situation has changed, and healthcare departments currently refuse to provide free healthcare to children of migrants, as they do not possess the $\mathrm{CHI}$ (Florinskaya).

\section{The right to a pension and unemployment benefits}

The serious legal obstacles for ensuring the social rights of migrants were and are the non-admission of foreign citizens and stateless persons into the social security system of Russia. The pension benefits and medical insurance schemes are closed to most newcomers (Shokhzoda, 2012). At the end of January 2014, the Russian Ministry of Labor sent the cabinet of ministers draft legislation obligating employers to buy sickness and maternity insurance for those workers who work in Russia but do not have either a permanent or temporary residence permit. Since January 1, 2015, maternity leave benefits, unemployment and pension benefits are available only to employees - citizens of the Eurasian Economic Union and Tajik labour migrants are still excluded from these social protection schemes.

In early 2016, Tajikistan and Russia announced an end to negotiations regarding pension provisions for Tajik labour migrants working in Russia. It is announced that currently, experts from both countries are working out the details 
of these agreements, as well as their implementation plan. The extent to which these agreements will be implemented and reinforced remains an open question. Russia and Tajikistan unfortunately have a history of failed negotiations, and agreements that never come to fruition, or which work for a short time only. For example, on October 29, 2013, the governments of Russia and Tajikistan signed an agreement on streamlining labour migration. In particular, it was decided to extend the term of the work permit from one to three years. Unfortunately, this provision was enforced for just over one year, and in 2014 Russia annulled this agreement and introduced labour patents.

\section{Conclusions}

The above analysis shows the close ties and dependencies that Russia and Tajikistan have. It also shows the power imbalance in the relationships of the two countries which impact policy development and implementation. Russia and Tajikistan as countries with diverse migration profiles (receiving country vs. sending country) confirm that national migration policy must take into account the demographic, economic and social needs of the country.

In order to achieve its proclaimed goals of improving its economic outlook and demographic situation, Russian needs to clearly face the reality that it needs a coherent and human-friendly migration policy, comprehensible migration mechanisms that are rooted in diversity, tolerance, and respect for human rights. Russia has a lot to learn in terms of integration mechanisms and ways of modifying migration flows.

In the case of Russia, making the country unattractive to migrants and posing unreasonable requirements will not help it achieve its economic development goals. Russia has proven to be a country with very strict but unclear immigration rules and implementation practices. Russian immigration policy is veiled in seemingly liberal slogans although its application is explicitly illiberal. Nowadays Russian reality is likely to teach immigrants coming to Russia a hard lesson.

In the case of Tajikistan, paying less attention to (re)integration migration mechanisms will force a dependence on migrant remittances and outwards migration. Tajikistan proclaims migration as a way to alleviate poverty at a national level, but the country faces a lack of coherent migration policy, and the impact of migrants returning from abroad to their country of origin and spending money in Tajikistan is also limited.

Both countries posed by gaps in their national migration policies and the lack of coordination between the migration mechanisms of Russia and Tajikistan. The current management of migration, in and between both countries, shows that each sets its migration policy less dependently of the other. The negative consequences of the current migration policy mismatch are rooted in migrant's human rights violations and the negative presumptions about migrants among Russian inhabitants. 


\section{REFERENCES}

1. Boswell, C. (2003). European Migration Policies in Flux: Changing Patterns of Inclusion and Exclusion. Oxford: Blackwell.

2. Eltis, D. (2002). Coerced and Free Migration: Global Perspectives. Stanford, CA: Stanford University Press. Introduction: pp. 1-32.

3. Geddes, A. (2002). The Politics of Migration and Immigration in Europe. London: Sage.

4. Gulina, O. (2016a). Demographic Component in the Right to Pension: Comparative Analysis of Russia and Germany. In: Rozanova, M. (ed.) Labor Migration and Migrant Integration in Germany and Russia. St. Petersburg: Scythia-Print, pp. 77-87.

5. Light, M. (2012). Migration Controls in Soviet and Post-Soviet Moscow: From "Closed City" to "Illegal City". In: Randolph, J. \& Avrutin, E. (eds) Russia in Motion. Cultures of Human Mobility since 1850. Chicago, IL: University of Illinois Press, pp. 80-100.

6. Malakhov, V. (2015). Integratsiia migrantov: kontseptsii i praktiki [The Integration of Migrants: Concepts and Practice]. Moscow: Mysl'.

7. Martin, D. (2003). The Authority and Responsibility of States. In: Aleinikoff, A.T \& Chetail, V (eds) Migration and International Legal Norms. The Hague: TMS Asser Press, pp. 31-45.

8. Martin, D. (2003). The Authority and Responsibility of States. In: Aleinikoff, A.T. \& Chetail, V. (eds) Migration and International Legal Norms. The Hague: TMS Asser Press, pp. 31-45.

9. Oblezova, A. (2016). Prava migrantov. In: Fedorova, O. (ed.) "Svoi" i "chuzhie": tolerantnost', stereotipy, prava [Rights of Migrants. In: Fedorova, O. (ed.) "Insiders" and "Outsiders": Tolerance, Stereotypes, Rights]. Moscow: MHG, pp. 58-98.

10. Penninx, R., Spencer, D. \& Van Hear, N. (2008). Migration and Integration in Europe: The State of Research. ESRC Centre on Migration, Policy and Society (COMPAS).

11. Rayazantzev, S. \& Horie, N. (2011). Modelirovanie potokov trudovoi migratsii iz stran Tsentral'noi Azii v Rossiiu [Modelling of Migration Flows from Central Asia to Russia]. Moscow: Nauchnyi Mir.

12. Thym, D. (2010). Migrationsverwaltungsrecht. Tübingen: Mohr Siebeck.

13. Torpey, J. (2000). The Invention of the Passport: Surveillance, Citizenship, and the State. Cambridge: Cambridge University Press.

14. Joppke, C. \& Moravska, E. (2014). Toward Assimilation and Citizenship. Immigrants in Liberal Nation-States. Palgrave Macmillan, pp: 1-36. 
15. Chudinovskikh, O., Kharaeva, O. \& Denisenko, M. (2004). Immigratsionnaia politika $v$ Rossiiskoi Federatsii i stranakh Zapada [Immigration policy in the Russian Federation and the Western countries]. Moscow: IEPP.

16. Schulte, A. \& Bayat, M. (2007). Migration und Integration. Wochenschau. Auflage: 1.

17. Spencer, I. (1997). British Immigration Policy since 1939. Oxford: Routledge.

18. Abashin, S. (2012). Sredneaziatskaya migratsiya: praktiki, lokal'nye soobshchestva, transnatsionalizm [Migration from Central Asia: Practices, Local Communities and Transnationalism]. Etnograficheskoe obozrenie, no 4, pp. 3-13.

19. Berg, E. \& Ehin, P. (2006). What Kind of Border Regime is in the Making? Towards a Differentiated and Uneven Border Strategy. Cooperation and Conflict, no 41, pp 53-71.

20. Berry, J.W. (1997). Immigration, Acculturation, and Adaptation, Applied psychology. An International Review, vol. 46, no 1, pp. 5-68.

21. Bjerre, L., Helbling, M., Römer, F. \& Zobel, M. (2015). Conceptualizing and Measuring Immigration Policies: A Comparative Perspective. International Migration Review, vol. 49, no 3, pp. 555-600.

22. Buckley, C. (1995). The Myth of Managed Migration: Migration Control and Market in the Soviet Period. Slavic Review, vol. 54, no 4, pp. 896-916.

23. Council of Europe (2002). European Committee on Migration. Towards a Migration Management Strategy. Available: http://www.coe.int/t/dg3/migration/archives/Documentation/Migration\%20management/Towards_Migration_Management_Strategy_ en.pdf (accessed: 7 October, 2016).

24. Craig, C. (2015). Migration and Integration. A local and Experiential Perspective. IRIS Working Paper Series, no 7. Available: http://www.birmingham.ac.uk/ Documents/college-social-sciences/social-policy/iris/2015/working-paper-series/ IRiS-WP-7-2015.pdf (accessed: 10 September, 2016).

25. Czaika, M. \& de Haas, H. (2013). The Effectiveness of Immigration Policies, Population and Development Review, vol. 39, no 3, pp. 487-508.

26. Haas de, H., Natter, K. \& Vezzoli, S. (2015). Conceptualizing and Measuring Migration Policy Change. Comparative Migration Studies, vol. 3, no 15. Available: Doi:10.1186/s40878-015-0016-5 (accessed: 1 December, 2016).

27. Duszczyk, M. \& Góra, M. (2012). Active Inclusion of Immigrants in Poland. IZA Discussion Papers 6427. Institute for the Study of Labor (IZA). Available: http:// www.iza.org/de/webcontent/publications/papers/viewAbstract?dp_id=6427 (accessed: 19 September, 2016).

28. Florinskaya, Y. (2012). Deti migrantov v Rossii: dostup k obrazovaniiu i meditsine [Migrants Children in Russia: Access to education and medicine]. Demoscope. Available: http://demoscope.ru/weekly/2012/0515/analit02.php (accessed: 27 September, 2016). 
29. GIZ (2012). Analysis of Migration Strategies in Selected Countries. Deutsche Gesellschaft fur Internationale Zusammenabeit (GIZ) GMbH. April.

30. Gradirovsky, S. (2010). Doklad. Politika repatriatsii i trudovol̆ migratsii v sovremennom rossiǔskom gosudarstve. [Report. The Repatriation Policy and Labor Migration in the Modern Russian State]. Moscow.

31. Gulina, O. (2016b). Strakh i nenavist'v Germanii: kak terror povliyayet na politiku strany [Fear and Hate in Germany: How Terror will Affect the Migration Policy of the Country Available: http://www.rbc.ru/opinions/society/26/07/2016/579712fb9a794 7eeda010ff3 (accessed: 7 September, 2016).

32. Gulina, O. (2016c). Zatrat na rubl', dokhod - na dva [One-ruble investment gives two-ruble benefits back]. Available: https://www.gazeta.ru/comments/2016/09/23_a_ 10211915.shtml\#page1 (accessed: 7 September, 2016).

33. Gulina, O. \& Utyasheva, L. (2016). Russia's Federal Migration Service Reform and Its Consequences. RUSMPI Newsletter. Available: http://www.rusmpi.org/publicationsпубликации/newsletter/ (accessed: 11 October, 2016).

34. Gulina, O. (2013). What troubles bring the introduction of visa regime with the Central Asian countries to Russia? Dialogi - webportal. Available: http://www.dialogi.su/ discussions/42/266.html (accessed: 7 September, 2016).

35. Houtkamp, C. (2015). Beyond Assimilation and Integration: The Shift to "National" and "Transnational” Inclusion. ACTA Univ. Sapientiae. European and Regional Studies, no 8, pp. 73-87.

36. Klepach, A. (2013). Russia’s Working-Age Population to Decline by $8-9 \%$ by 2020 Deputy Minister. Interfax news. 28 February. Available: http://www.interfax.com/ newsinf.asp?id=399564 (accessed: 28 August, 2016).

37. Kosnik, K. (2014). Final Remarks to the Midterm Conference of ESA-RN 35. Sociology of Migration Contested Migration Regimes: European Perspectives and Beyond. Frankfurt/Main, 13-14 November. Available: http://www.europeansociology.org/ docs/RNs/RN35/Final\%20Remarks.pdf (accessed: 3 September, 2016).

38. Kuznetsova, I. \& Mukharyamova, L. (2014). Trudovyye migranty v sisteme meditsinskikh uslug: formal'nyje i neformal'nyje strategii [Migrant Workers in the Health Care System: The Formal and Informal Strategies]. Zhurnal Issledovaniy Sotsial'noy Politiki, vol. 12, no 1. pp. 7-20.

39. Levada (2013). Levada Centre Polling. May and June, 2013. Available: http://www. levada.ru/issledovaniya (accessed: 7 October, 2016).

40. Mayda, A.M. \& Patel, K. (2004). OECD Countries Migration Policy Changes. In: Mayda, A.M. International Migration: A Panel Data Analysis of Economic and Non-Economic Determinants. Available: http://faculty.georgetown.edu/amm223/policychangesAppendix.pdf (accessed: 10 October, 2016).

41. Memorial Alternative Report (2014). The Situation of Children Belonging to Vulnerable Groups in Russia. Alternative Report. ADC. Available: http://adcmemorial.org/ wp-content/uploads/crs_eng_www.pdf (accessed: 1 December, 2016). 
42. PICUM (2015). Undocumented Migrants and the Europe 2020 Strategy: Making Social Inclusion a Reality for all Migrants in Europe. PICUM Position Paper. Available: http://picum.org/picum.org/uploads/publication/Undocumented\%20 Migrants\%20and\%20the\%20EU2020\%20Strategy_FINAL.pdf (accessed: 15 September, 2016).

43. Putin, V. (2012). Rossiia: natsional'nyi vopros [Russia: the National Question]. Nezavisimaia gazeta. 23.1.2012.

44. RIA Novosti (2015). The Head of the Federal Migration Service: in 2015 the Numbers of Migrants in Russia Has Stabilized. RIA Novosti. 02.01.16. Available: https:// ria.ru/society/20160102/1353262641.html (accessed: 21 September, 2016).

45. Rinne, U. (2012). The Evaluation of Immigration Policies. IZA DP N 6369. Forschungsinstitut zur Zukunft der Arbeit. February 2012. Available: http://ftp. iza.org/dp6369.pdf (accessed: 7 October, 2016).

46. Ruedin, D. \& D’Amato, G. (2011). Social Cohesion Challenges in Europe. EU-US Immigration Systems 2011/04. Robert Schuman Centre for Advanced Studies. San Domenico di Fiesole (FI): European University Institute.

47. Ruhs, M. (2011). Openness, Skills and Rights: An Empirical Analysis of Labour Immigration Programs in 46 High- and Middle-Income Countries. COMPAS Working Paper Series. Oxford: COMPAS.

48. Ryazantsev, S. (2016). Labour Migration from Central Asia to Russia in the Context of the Economic Crisis. Valdai Discussion Club. Valdai Papers, no 55, August. Available: http://eng.globalaffairs.ru/valday/Labour-Migration-from-CentralAsia-to-Russia-in-the-Context-of-the-Economic-Crisis-18334 (accessed: 16 October, 2016).

49. Saggar, S., Somerville, W. \& Ford, R. \& Sobolewska, M. (2012). The Impact of Migration on Social Cohesion and Integration. Available: https:/www.gov.uk/government/ uploads/system/uploads/attachment_data/file/258355/social-cohesion-integration. pdf (accessed: 15 September, 2016).

50. Salter, M. (2004). Passport, Mobility and Security: How Smart Can the Border Be? International Studies Perspectives, no 5, pp. 71-91.

51. Schenk, C. (2015). Labor Migration in the Eurasian Union: Will Freedom of Movement Trump Domestic Controls? PONARS Eurasia Policy Memo N 378. Available: http://www.ponarseurasia.org/sites/default/files/policy-memos-pdf/Pepm378_ Schenk_Aug2015.pdf (accessed: 5 August 2016).

52. Sedelmeyer, U. (2002). Sectoral Dynamic of EU Enlargement: Advocacy, Access and Alliances in a Composite Policy. Journal of European Public Policy, no 9, pp. 627-649.

53. Shokhzoda, S. (2012). Rossiyskaya Federatsiya. Sbornik analiticheskikh dokladov. Zashchita sotsial'nykh i trudovykh prav migrantov na prostranstve SNG [Russian Federation. The Collection of Analytical Reports. The Protection of Social and Labor Rights of Migrants in the CIS]. ILO 2012. 
54. UNGASS country report (2008). Tajikistan National AIDS Spending Assessment, 20082009. Available: http://files.unaids.org/en/media/unaids/contentassets/dataimport/pub/ report/2008/NASA_TAJIKISTAN_2008-2009_en.pdf (accessed: 7 September, 2016).

55. Varshaver, E. \& Rocheva, A. (2016). Integratsiia migrantov: chto eto i kakuiu rol' v ee osushchestvlenii mozhet igrat' gosudarstvo [Integration of Migrants: What It Is and what the Role Can a State Play in its Implementation]. Zhurnal Issledovanii Sotsial'noi Politiki, vol. 14, no 3, pp. 315-330.

56. WHO-Europe (2014). HIV Programme Review in Tajikistan. Evaluation Report. Available: http://www.euro.who.int/_data/assets/pdf_file/0008/270539/HIVProgramme-Review-in-Tajikistan.pdf?ua=1 (accessed: 16 October, 2016).

57. Wodak, R. (2016). Integration and Culture. From "Communicative competence" to "Competence of Plurality". Available: https://youtu.be/qF5l21CeO0Q (accessed: 15 October, 2016).

58. World Bank (2016). Migration and Remittances. Recent Developments and Outlook. Migration and Development Brief, no 26. April.

59. Yevplanov, A. (2013). Polis dlya migranta [Insurance Policy for Migrants]. Rossiiskaia gazeta, 30 July.

60. Zayonchkovskaya, Z. (2016). Zhanna Zayonchkovskaya's Speech. Session 6. Prospects for Russia's Participation in International Regulation. RIAC Conference in Moscow, Russia in September 22-23, 2016. Available: http://russiancouncil.ru/ inner/?id_4=8052\#top-content (accessed: 26 December, 2016). 


\section{LEGAL DOCUMENTS}

1. Central Bank (2015). Statistics of the cross-border transfers of individuals. Available: http://www.cbr.ru/statistics/?Prtid=svs\&ch=Par_17101\#CheckedItem (accessed: 15 September, 2016).

2. Constitutional Court of Russian Federation (2015). Postanovlenie Konstitutsionnogo Suda RF ot 12.03.2015 N 4-P "Po delu o proverke konstitutsionnosti polozhenii chasti chetvertoi stat'i 25.10 Federal'nogo zakona "O poriadke vyezda iz Rossiiskoi Federatsii i v'ezda v Rossiiskuiu Federatsiiu”, podpunkta 13 punkta 1 stat'i 7 Federal'nogo zakona "O pravovom polozhenii inostrannykh grazhdan v Rossiiskoi Federatsii" i punkta 2 stat'i 11 Federal'nogo zakona "O preduprezhdenii rasprostraneniia v Rossiiskoi Federatsii zabolevaniia, vyzyvaemogo virusom immunodefitsita cheloveka (VICh-infektsii)" v sviazi s zhalobami riada grazhda. Available: http://www.consultant.ru/document/cons_doc_LAW_176615/(accessed: 21 September, 2016).

3. Cooperation Program of the ILO and Tajikistan (2013). Cooperation Program between tripartite partners of republic of Tajikistan and ILO for decent work (2015-2017). Approved by the resolution of the Republic of Tajikistan N 10 of February 28, 2015.

4. Decree of President of the Russian Federation of April 5, 2016. [Ukaz Prezidenta RF O sovershenstvovanii gosudarstvennogo upravleniya v sfere kontrolia za oborotom narkoticheskikh sredstv, psikhotropnykh veshchestv i ikh prekursorov i v sfere migratsii]. Available: http://kremlin.ru/acts/news/51649 (accessed: 16 October, 2016).

5. Demographic Concept (2015). Concept of Russia’s demographic development until 2015. Kontseptsiia gosudarstvennoy migratsionnoi politiki Rossiyskoy Federatsii na period do 2025 goda. (The document has not been published). Available: http://base.consultant.ru/cons/cgi/online.cgi? req=doc;base=LAW;n=131046 (accessed: 21 September, 2016).

6. EU Commission (2015). A European Agenda on Migration. Available: http:// ec.europa.eu/dgs/home-affairs/what-we-do/policies/european-agenda-migration/ background-information/docs/communication_on_the_european_agenda_on_ migration_en.pdf (accessed: 21 September, 2016).

7. Federal Law 114-FZ of August 15, 1996. On the Legal Entry to and Exit from the Territory of Russian Federation. [Federal'nyi zakon N 114-FZ "O poryadke vyezda iz Rossiyskoy Federatsii i v'ezda v Rossiyskuyu Federatsiyu”]. Available: http://www.consultant.ru/document/cons_doc_LAW_11376/ (accessed: 13 September, 2016).

8. Federal State Statistics (2015). Federal State Statistics Service of the Russian Federation. Demographic Yearbook of Russia of 2014. [Federalnaya sluzhba gosudarstvennoy statistiki RF. Demograficheskiy Ezhegodnik Rossii”]. Available: http:// www.gks.ru/bgd/regl/B14_16/Main.htm (accessed: 10 September, 2016). 
9. Federal Law N 109-FZ of June 18, 2006. On Migration Registration of Foreigners and Stateless Persons [Federal'nyi zakon N 109-FZ "O Migratsionnom uchete inostrantsev i liudey bez grazhdanstva v Rossiyskoi Federatsii]. Available: http://www. consultant.ru/document/cons_doc_LAW_61569/ (accessed: 13 September, 2016).

10. Federal Law N 115-FZ of June 25, 2002. On Legal Status of Foreigners and Stateless Persons on the territory of the Russian Federation [Federal'nyi zakon N 115-FZ "O pravovom polozhenii inostrantsev i liudey bez grazhdanstva na territorii Rossiyskoy Federatsii]. Available: http://www.consultant.ru/document/cons_doc_LAW_37868/ (accessed: 13 September, 2016).

11. Federal Law N 185 FZ of November 11, 2012. On amending Article 13.1 of the Federal Law "On the legal status of foreigners in the Russian Federation", and Article 27.2 of the Law "On education" ["O vnesenii izmeneniy v Stat'yu 13.1 Federalnogo zakona "O pravovom polozhenii inostrantsev in Rossiiskoi Federatsii", i Stat'yu 27.2 Zakona RF "ob obrazovanii"']. Available: http://www.consultant.ru/document/ cons_doc_LAW_140537/(accessed: 21 September, 2016).

12. Federal Law N 212-FZ of July 24, 2009. About Insurance Fees in to the Pension Fund of the Russian Federation, Social Insurance Fund of the Russian Federation, the Federal Compulsory Medical Insurance Fund and Their Territorial Health Insurance Departments [Federal'nyi zakon N 212-FZ "O strakhovykh vznosakh v Pensionnyi Fond RF, Fond Sotsialnogo strakhovaniya FR, Federalnyi Fond obyazatelnogo meditsinskogo strakhovaniya"]. Available: http://www.consultant.ru/document/ cons_doc_LAW_89925/ (accessed: 13 September, 2016).

13. Federal Law N 376-FZ of December 21, 2013. On Amending the Art. 27 Law 114-FZ "On the Procedure for Exiting and Entering the Russian Federation" and Art. 5 of Law 115-FZ "On the Legal Status of Foreign Citizens in the Russian Federation" [Federal'nyi zakon N 376-FZ “O vnesenii izmeneniy v otdel'nyye zakonodatel'nyye akty Rossiyskoy Federatsii”]. Available: http://www.rg.ru/2013/12/25/izmeneniya1dok.html (accessed: 10 September, 2016).

14. Federal Law N 62-FZ of May 31, 2002 On citizenship [Federal'nyy zakon N 62-FZ O grazhdanstve v RF]. Available: http://www.consultant.ru/document/cons_doc_ LAW_36927/ (accessed: 10 September, 2016).

15. Federal Law N 99-FZ of May 24, 1999 On the State Policy of the Russian Federation Regarding Compatriots Abroad [Federal'nyi zakon N 99-F3 O gosudarstvennoi politike v otnoshenii sootechestvennikov za rubezhom]. Available: http://www.consultant.ru/document/cons_doc_LAW_23178/ (accessed: 13 September, 2016).

16. FMS Order (2012). The document has not been published [Prikaz FMS RF N 412 ot 8.11.2012 Ob utverzhdenii Polozheniia ob Upravleniia sodeistviia integratsii FMS RF]. Available: http://www.consultant.ru (accessed: 29 September, 2016).

17. Government Regulation N 2197-P of October 29, 2015 [Rasporiazhenie Pravitel'stva RF ot 29.10.2015 N 2197-r Ob ustanovlenii kvoty na vydachu inostrannym grazhdanam i litsam bez grazhdanstva razreshenii na vremennoe prozhivanie v Rossiiskoi Federatsii na 2016 god]. Available: http://www.consultant.ru/document/cons_doc_ LAW_188199/ (accessed: 29 September, 2016). 
18. Government Regulation N 891 of October 8, 2013 [Postanovlenie Pravitel'stva Rossiiskoi Federatsii ot 8 oktiabria 2013 g. N 891 g. Moskva "Ob ustanovlenii kvoty na obrazovanie inostrannykh grazhdan i lits bez grazhdanstva v Rossiiskoi Federatsii]. Available: https://rg.ru/2013/10/10/obuchenie-site-dok.html (accessed: 29 September, 2016).

19. Kuwait-Tajikistan Agreements (2011): Tajikistan- Kuwait Agreement of August 16, 2011. Available: http://www.migration.tj/index.php/en/news/86-news/news/957hjjjjk (accessed: 28 September, 2016).

20. Law Draft (2014). Law Draft on Social and Cultural Adaptation of Immigrants of February 28, 2014. Available: http://www.fms.gov.ru/documentation/865/details/81610/ (accessed: 7 January, 2015).

21. Migration Concept (2012). Concept of State Migration Strategy of the Russian Federation until 2025 [Kontseptsiia gosudarstvennoi migratsionnoi politiki Rossiiskoi Federatsii na period do 2025 goda]. Available: http://www.consultant.ru/document/ cons_doc_LAW_131046/ (accessed: 16 October, 2016).

22. President Decree N 1289 of September 14, 2012 [Ukaz Prezidenta RF ot 14.09.2012 $\mathrm{N}$ 1289. "O realizatsii Gosudarstvennoi programmy po okazaniiu sodeistviia dobrovol'nomu pereseleniiu v Rossiiskuiu Federatsiiu sootechestvennikov, prozhivaiushchikh za rubezhom”]. Available: http://base.garant.ru/70227698/\#ixzz4Mfo1TNgt (accessed: 9 October, 2016).

23. President Decree N 1325 of November 14, 2002a [Ukaz Prezidenta RF ot 14.11.2002 N 1325 "Ob utverzhdenii polozheniia o poriadke rassmotreniia voprosov grazhdanstva RF”, pri podache dokumentov na grazhdanstvo neobkhodimo predostavit' dokument, podtverzhdaiushchii vladenie zaiavitelia russkim iazykom na urovne, dostatochnom dlia obshcheniia $\mathrm{v}$ ustnoi i pis'mennoi forme $\mathrm{v}$ usloviiakh iazykovoi sredy]. Available: http://www.consultant.ru/document/cons_doc_LAW_39607/ (accessed: 8 October, 2016).

24. Republic of Tajikistan, Government Decree N 144 of April 3, 2012 [Ob utverzhdenii Gosudarstvennoi programmy po realizatsii Kontseptsii prognoznogo razvitiia zakonodatel'stva Respubliki Tadzhikistan v sferakh truda, sotsial'noi zashity i obrazovaniia na 2012-2015 gody]. Available: http://mmk.tj/ru/Government-programs/ programs/work) (accessed: 7 October, 2016).

25. Republic of Tajikistan, Government Regulation (2013). Law on Migration with amendments [Zakon Respubliki Tadzhikistan N 881 of December 11, 1999 O migratsii]. Available: http://www.migration.tj/index.php/ru/zakonodatelstvo/omigratio (accessed: 7 October, 2016).

26. Republic of Tajikistan, Government Regulation N 242 of June 9, 2001 with amendments according Government Regulation N 532 of August 7, 2014 [Postanovlenie Pravitel'stva Respubliki Tadzhikistan ot 9 iiunia 2001 goda N 242 O Kontseptsii trudovoi migratsii grazhdan Respubliki Tadzhikistan za granitsu]. Available: http://base.spinform.ru/show_doc.fwx?rgn=5756 (accessed: 7 October, 2016). 
27. Republic of Tajikistan, Government Regulation N 460 of October 4, 2011 [Postanovlenie Pravitel'stva Respubliki Tadzhikistan, Ob utverzhdenii Natsional'noi strategii trudovoi migratsii grazhdan Respubliki Tadzhikistan za rubezh na period 20112015 godov]. Available: http://www.migration.tj/index.php/ru/zakonodatelstvo/ strategy (accessed: 17 October, 2016).

28. Republic of Tajikistan, Law of the Republic of Tajikistan on the Legal Status of Foreign Citizens N 230 of February 1, 1996, with amendments [Zakon Respubliki Tadzhikistan O pravovom polozhenii inostrannykh grazhdan v Respublike Tadzhikistan]. Available: http://www.migration.tj/index.php/ru/zakonodatelstvo/2013-04-14-08-52-24 (accessed: 7 October, 2016).

29. Republic of Tajikistan, Law on Improvement of Employment (2003) [Zakon Respubliki Tadzhikistan N 44 of July 16, 2003 O sodeistvii zaniatosti naseleniia]. Available: http://www.mehnat.tj/pdf_doc/16sodeystvii_naseleniya.pdf (accessed: 7 October, 2016).

30. Republic of Tajikistan, Migration Concept (1998) [Postanovlenie pravitel'stva Respubliki Tadzhikistan N 411 ot 8 oktiabria 1998 godu, Ob utverzhdenii Kontseptsii gosudarstvennoi migratsionnoi politiki Respubliki Tadzhikistan]. Available: http:// base.spinform.ru/show_doc.fwx?rgn=83791 (accessed: 7 October, 2016).

31. Republic of Tajikistan, National Program on the Enhancement of Employment for 2016-201 (2015) [O Gosudarstvennoi programme sodeistviia zaniatosti naseleniia Respubliki Tadzhikistan na 2016-2017 gody]. Available: http://base.spinform. ru/show_doc.fwx?rgn=81466 (accessed: 15 September, 2016).

32. Republic of Tajikistan's Government Decree N 218 of May 15, 1999 [Postanovlenie Pravitel'stva Respubliki Tadzhikistan ot 15 maia 1999 goda N 218 "Ob utverzhdenii Pravil prebyvaniia inostrannykh grazhdan v Respublike Tadzhikistan i Pravil tranzitnogo proezda inostrannykh grazhdan cherez territoriiu Respubliki Tadzhikistan]. Available: http://www.adlia.tj/show_doc.fwx?rgn=12337 (accessed: 7 October, 2016).

33. Republic of Tajikistan's State Program on Employment (2014). State Program on Employment of Citizens of Republic of Tajikistan of 3 January 2014 [Gosudarstvennaia programma sodeistviia zaniatosti naseleniia Respubliki Tadzhikistan na 2014-2015 gody ot 3 ianvaria 2014 goda, N 19]. Available: http://base.spinform. ru/show_doc.fwx?rgn=65523 (accessed: 7 October, 2016).

34. Republic of Tajikistan's State Strategy of the Development of the Labour Market until 2020 (2011) [Gosudarstvennaia strategiia razvitiia rynka truda. Respubliki Tadzhikistan do 2020 goda]. Available: www.kor.tj/public/userfiles/docs/5Государственная\%20 стратегиях.pdf (accessed: 15 September, 2016).

35. Russia's Ministry of Education Decree N 844 of July 28, 2014. On establishing guidelines for the selection of foreign nationals and stateless persons for studying in the Russian Federation [Prikaz Ministerstva obrazovaniia i nauki Rossiiskoi Federatsii (Minobrnauki Rossii) ot 28 iiulia 2014 g. N 844 g. Moskva "Ob utverzhdenii Poriadka otbora inostrannykh grazhdan i lits bez grazhdanstva na obuchenie v predelakh 
ustanovlennoi Pravitel'stvom Rossiiskoi Federatsii kvoty na obrazovanie inostrannykh grazhdan i lits bez grazhdanstva v Rossiiskoi Federatsii”]. Available: https:// rg.ru/2014/12/17/inostranci-dok.html (accessed: 21 September, 2016).

36. Russia-Tajikistan Agreements (1992). [Soglashenie mezhdu Respublikoi Tadzhikistan i Rossiiskoi Federatsiei o regulirovanii protsessov pereseleniia i zashchite prav pereselentsev ot 10 oktiabria 1992 goda]. Available: http://base.spinform.ru/show_doc. fwx? $r g n=25482$ (accessed: 21 September, 2016).

37. Russia-Tajikistan Agreements (2013). [Soglashenie mezhdu Respublikoi Tadzhikistan i Pravitel'stvom Rossiiskoi Federatsii o poriadke prebyvaniia grazhdan Respubliki Tadzhikistan na territorii Rossiiskoi Federatsii ot 8 fevralia 2013 goda]. Available: http://kremlin.ru/acts/news/19981 (accessed: 21 September, 2016).

38. St. Petersburg's Program (2010). [Programma garmonizatsii mezhkul'turnykh, mezhetnicheskikh i mezhkonfessional'nykh otnoshenii, vospitaniia kul'tury tolerantnosti v Sankt-Peterburge na 2011-2015 gody]. Available: http://sniper.zelenogorsk-spb. ru/docs/Tolerantnost_2011-2015.pdf (accessed: 21 September, 2016).

39. State Program on Employment of Citizens of Republic of Tajikistan (2015). [Gosudarstvennaia programma sodeistviia zaniatosti naseleniia Respubliki Tadzhikistan na 2016-2017 gody]. Available: http://www.adlia.tj/show_doc.fwx?rgn=125831 (accessed: 21 September, 2016).

40. Tajikistan's Government Regulation (2001). National Concept for Labour Migration by Tajik Citizens Abroad of June 9, 2001 [Natsional'naia Strategiia trudovoi migratsii grazhdan Respubliki Tadzhikistan za rubezh]. Available: http://base.spinform.ru/ show_doc.fwx?rgn=5756 (accessed: 15 September, 2016).

41. Tajikistan's Migration Concept (1998). [Kontseptsiia Gosudarstvennoi migratsionnoi politiki Respubliki Tadzhikistan]. Available: http://www.migration.tj/index.php/ru/ zakonodatelstvo/sogl-2 (accessed: 10 September, 2016). 